\title{
Effects of different levels of dietary sulfur and molybdenum on concentrations of copper and other elements in plasma and liver of lambs fed palm kernel cake diets
}

\author{
A. R. Alimon, M. Ivan* and S. Jalaludin \\ Institute of Tropical Agriculture, University Putra Malaysia, 43400 UPM Serdang, Selangor, Malaysia \\ (Received 9 November 2010 - Revised 19 January 2011 - Accepted 21 February 2011 - First published online 15 April 2011)
}

\begin{abstract}
A 6-month experiment with nine dietary treatments was conducted to determine amounts of S plus Mo supplements required to maintain normal hepatic concentrations of $\mathrm{Cu}$ and $\mathrm{Mo}$ and to prevent chronic Cu toxicity in lambs fed palm kernel cake (PKC) diets. All diets consisted of PKC supplemented with minerals and vitamins, and with appropriate amounts per kg DM of S (level 0 or level $1=1 \mathrm{~g}$ ) as sodium sulfate and/or Mo (level 0 ; level $1=4 \mathrm{mg}$; level $2=8 \mathrm{mg}$; level $3=16 \mathrm{mg}$; level $4=32 \mathrm{mg}$ ) as ammonium molybdate to form treatments S0Mo1, S0Mo2, S0Mo3, S0Mo4, S1Mo0, S1Mo1, S1Mo2, S1Mo3 and S1Mo4. There was no effect $(P>0 \cdot 05)$ of dietary treatments on the growth performance of the lambs. The dietary supplement of $1 \mathrm{~g} \mathrm{~S}$ plus $8 \mathrm{mg}$ Mo per kg dietary DM (treatment S1Mo2) prevented accumulation of $\mathrm{Cu}$ in the liver without elevation of the concentration of Mo $(P>0.05)$. The treatments S0Mo1, S0Mo2 and S0Mo3 increased $(P<0.05)$ hepatic $\mathrm{Cu}$ concentrations from $376 \mu \mathrm{g} / \mathrm{g}$ DM to between 1090 and $1294 \mu \mathrm{g} / \mathrm{g}$ DM. Also, the treatments S1Mo3 and S1Mo4 resulted in higher $(P<0.05)$ hepatic Mo concentrations compared with the treatment S1Mo0. It was concluded that the dietary supplement of $1 \mathrm{~g} \mathrm{~S}$ plus $8 \mathrm{mg} \mathrm{Mo} / \mathrm{kg}$ PKC DM added to the PKC used is sufficient to maintain normal hepatic concentrations of Cu and Mo and to prevent chronic $\mathrm{Cu}$ toxicity in sheep fed diets containing any amount of PKC.
\end{abstract}

Key words: Copper: Molybdenum: Sulfur: Palm kernel cake: Lambs

Palm kernel cake (PKC) is a by-product of the palm oil industry. Malaysia is the world's largest producer of palm oil and obviously of PKC, which, with its content of 14 to $16 \%$ crude protein and 9.5 to $10.5 \mathrm{MJ}$ metabolisable energy per $\mathrm{kg}$, is a good feed for ruminants ${ }^{(1)}$ and is exported to Europe in high quantities for use in diets of dairy and beef cattle. However, PKC also contains high amounts (11 to $55 \mathrm{mg} / \mathrm{kg} \mathrm{DM}$ ) of $\mathrm{Cu}^{(1-3)}$, which is potentially toxic to sheep due to their relative sensitivity to excessive dietary $\mathrm{Cu}$ as compared with cattle ${ }^{(4)}$. In addition, the $\mathrm{Cu}$ in PKC is highly soluble in the rumen ${ }^{(5)}$ and its absorption is elevated due to the absence of rumen ciliate protozoa ${ }^{(6)}$ resulting from feeding $\mathrm{PKC}^{(7)}$. Because the excess of absorbed $\mathrm{Cu}$ is accumulated in internal organs, mainly the liver, which are consumed by humans, it is important to use dietary means to decrease the dietary $\mathrm{Cu}$ absorption and tissue accumulation not only in sheep, but in all ruminants fed PKC regardless of their susceptibility to the chronic $\mathrm{Cu}$ toxicity. Several dietary supplements and their combinations ( $\mathrm{S}, \mathrm{Mo}, \mathrm{Fe}, \mathrm{Zn}$, bentonite, etc) have been shown to decrease dietary $\mathrm{Cu}$ absorption. However, supplements of $\mathrm{S}$ plus Mo appear to be most effective ${ }^{(8)}$. Although a high number of experiments on effects of S-Mo supplements in PKC-based diets have been conducted in Malaysia and the results presented at local conferences, only a small proportion has been published in scientific journals. In addition, no optimal amounts of supplemental $S$ and Mo required in dietary PKC to prevent chronic Cu toxicity in ruminants have been established. Since high concentrations in the liver of both $\mathrm{Cu}$ and Mo could be harmful to consumers, it is important that not only the concentration of $\mathrm{Cu}$, but Mo also, is monitored when dietary Mo supplements are used to decrease the $\mathrm{Cu}$ absorption from the dietary PKC. It was, therefore, the main objective of the present experiment to establish optimal amounts of dietary $\mathrm{S}$ and/or Mo needed to decrease the absorption of $\mathrm{Cu}$ from PKC-based diets to an acceptable level, without excessive accumulation of dietary Mo in the liver of lambs. An additional objective was to monitor potential negative effects of S-Mo supplements on the growth and feed intake of lambs. The objectives have been achieved and the results are presented in the present paper.

Abbreviation: PKC, palm kernel cake.

*Corresponding author: Dr Michael Ivan, fax +603 8946 8968, email mivan@putra.upm.edu.my 


\section{Materials and methods}

A total of eighty Malin cross lambs, aged approximately 8 months, with body weight of 14.2 (SD 0.9) $\mathrm{kg}$ were used in the present 6-month feeding experiment. Of the eighty lambs, eight were randomly selected at the start of the experiment (before feeding the experimental diets), and after sampling of blood the lambs were slaughtered and their livers were removed and sampled. The concentrations of mineral elements in the plasma and liver samples of the lambs were used to establish the starting baseline concentrations.

The remaining seventy-two lambs were divided according to live weight into two blocks (large and small). Thereafter, four lambs from each block were assigned at random to nine treatment groups of eight lambs each. The treatment groups were housed in individual pens with wooden slotted flooring and automatic water drinking nipples in an open wooden sheep barn raised above the ground. Each group was fed ad libitum one of nine total mixed experimental diets (Table 1). Feed refusals were collected, weighed and sampled daily. The diets were based entirely on solventextracted PKC and supplemented with limestone to correct for the Ca:P imbalance in PKC, due to its relatively high $\mathrm{P}$ $(4.37 \mathrm{~g} / \mathrm{kg} \mathrm{DM})$ and lower $\mathrm{Ca}(2 \cdot 80 \mathrm{~g} / \mathrm{kg} \mathrm{DM})$ concentrations. Individual diets were also supplemented with sodium sulfate $\left(\mathrm{Na}_{2} \mathrm{SO}_{4}\right)$ as the source of dietary $\mathrm{S}$ and/or ammonium molybdate $\left(\left(\mathrm{NH}_{4}\right)_{6} \mathrm{Mo}_{7} \mathrm{O}_{2} 4 \cdot 4 \mathrm{H}_{2} \mathrm{O}\right)$ as the source of the dietary Mo. There were two levels of supplemental S; level 0 (SO) or level 1 (S1 = $1 \mathrm{~g} \mathrm{~S} / \mathrm{kg} \mathrm{DM})$ and four levels of supplemental Mo; level 0 (Mo0), level 1 (Mo1 = $4 \mathrm{mg} \mathrm{Mo} / \mathrm{kg} \mathrm{DM})$, level 2 $(\mathrm{Mo} 2=8 \mathrm{mg} \mathrm{Mo} / \mathrm{kg} \mathrm{DM})$, level $3(\mathrm{Mo} 3=16 \mathrm{mg} \mathrm{Mo} / \mathrm{kg} \mathrm{DM})$ and level $4(\mathrm{Mo} 4=32 \mathrm{mg} \mathrm{Mo} / \mathrm{kg} \mathrm{DM})$. This was in addition to the PKC content of S (approximately $2 \mathrm{~g} / \mathrm{kg} \mathrm{DM}$ ) and Mo (approximately $0.8 \mathrm{mg} / \mathrm{kg} \mathrm{DM}$ ). Therefore, there were nine dietary treatments in the experiment: (1) SOMo1, (2) SOMo2, (3) SOMo3, (4) S0Mo4, (5) S1Mo0, (6) S1Mo1, (7) S1Mo2, (8) S1Mo3 and (9) S1Mo4. Because lambs fed a PKC diet without a dietary $\mathrm{S}$ or Mo supplement could die due to $\mathrm{Cu}$ toxicity before a 6-month experiment is completed ${ }^{(8,9)}$, it was decided that feeding a control PKC monodiet (PKC plus appropriate vitamins and mineral supplements) without both sodium sulfate and ammonium molybdate supplements ( $\mathrm{SOMOO}$ ) would not be practical. Consequently, such a control diet was not included in the present experiment. The PKC was sampled and diets mixed and sampled every $10 \mathrm{~d}$. The samples (including feed refusals) were dried in an oven over $2 \mathrm{~d}$ at $60^{\circ} \mathrm{C}$, ground through a $1 \mathrm{~mm}$ sieve and stored at $-20^{\circ} \mathrm{C}$. The PKC used in the present experiment contained (per $\mathrm{kg} \mathrm{DM}$ ) crude protein, $140 \mathrm{~g}$; acid-detergent fibre, $443 \mathrm{~g}$; Cu, $24.6 \mathrm{mg}$; Zn, $35.4 \mathrm{mg}$; Mn, $102 \mathrm{mg}$; Fe, $1.21 \mathrm{~g}$; Ca, $2.80 \mathrm{~g}$; P, $4.37 \mathrm{~g}$; Mg, $1.83 \mathrm{~g}$. The total mixed diets were bagged and kept in a cold place. All lambs were weighed on two consecutive days at the beginning and the end of the experiment, following an overnight withdrawal of food and water. The average of the two consecutive weighing was recorded and considered as the mean of the initial or final live weight. The lambs were also weighed and weights recorded at monthly intervals during the experiment. Blood samples were obtained at the beginning and the end of the experiment. Individual feed intakes were recorded daily and the lambs had free access to fresh drinking water. Care of the experimental animals was in accordance with the Malaysian standards (including Halal slaughter) and the experimental protocol was approved by the Institutional Animal Care and Use Committee.

During the second month of the experiment, one lamb from each of the SOMo1 and S0Mo4 treatments was removed from the experiment due to decreased feed intakes, most probably resulting from the environmental stress (hot and humid local climate). Similarly, one lamb from each of the S0Mo4 and S1Mo0 treatments was removed during the third month of the experiment. The data from these lambs were removed from the records. After 3 months, two (treatments S0Mo1, S0Mo4, S1Mo0 and S1Mo4) or three (treatments S0Mo2,

Table 1. Composition of the experimental diets

\begin{tabular}{|c|c|c|c|c|c|c|c|c|c|}
\hline Diet $^{*} \ldots$ & SoMo1 & SOMo2 & SOMo3 & SOMo4 & S1Mo0 & S1Mo1 & S1Mo2 & S1Mo3 & S1Mo4 \\
\hline \multicolumn{10}{|l|}{ Ingredients (g/kg DM) } \\
\hline Palm kernel cake & 961.4 & 961.4 & 961.4 & $961 \cdot 3$ & $957 \cdot 0$ & $957 \cdot 0$ & $957 \cdot 0$ & $957 \cdot 0$ & $956 \cdot 9$ \\
\hline Cobalt-iodised salt & $10 \cdot 0$ & $10 \cdot 0$ & $10 \cdot 0$ & $10 \cdot 0$ & $10 \cdot 0$ & $10 \cdot 0$ & $10 \cdot 0$ & $10 \cdot 0$ & $10 \cdot 0$ \\
\hline Limestone & $28 \cdot 0$ & $28 \cdot 0$ & $28 \cdot 0$ & $28 \cdot 0$ & $28 \cdot 0$ & $28 \cdot 0$ & $28 \cdot 0$ & $28 \cdot 0$ & $28 \cdot 0$ \\
\hline Sodium sulfate & - & - & - & - & 4.4 & 4.4 & 4.4 & 4.4 & 4.4 \\
\hline Vitamins $A$ and $\mathrm{E} \dagger$ & 0.6 & 0.6 & 0.6 & 0.6 & 0.6 & 0.6 & 0.6 & 0.6 & 0.6 \\
\hline Ammonium molybdate & 0.013 & 0.026 & 0.052 & 0.103 & - & 0.013 & 0.026 & 0.052 & 0.103 \\
\hline \multicolumn{10}{|l|}{ Chemical analysis } \\
\hline Crude protein (g/kg DM) & 146 & 139 & 143 & 137 & 148 & 145 & 152 & 139 & 146 \\
\hline ADF $(g / k g ~ D M)$ & 434 & 438 & 450 & 447 & 433 & 447 & 461 & 444 & 439 \\
\hline $\mathrm{Ca}(\mathrm{g} / \mathrm{kg} \mathrm{DM})$ & $4 \cdot 10$ & $6 \cdot 16$ & $5 \cdot 16$ & 6.00 & $5 \cdot 34$ & $5 \cdot 30$ & 5.06 & 4.82 & 5.65 \\
\hline $\mathrm{Mg}(\mathrm{g} / \mathrm{kg} \mathrm{DM})$ & $1 \cdot 35$ & $1 \cdot 72$ & $1 \cdot 78$ & 1.79 & 1.42 & 1.44 & 1.42 & $1 \cdot 80$ & 1.64 \\
\hline$P(g / k g ~ D M)$ & 4.83 & $4 \cdot 15$ & $5 \cdot 19$ & $4 \cdot 74$ & $5 \cdot 07$ & $4 \cdot 31$ & $5 \cdot 00$ & $4 \cdot 27$ & 4.83 \\
\hline $\mathrm{Fe}(\mathrm{g} / \mathrm{kg} \mathrm{DM})$ & $1 \cdot 28$ & 1.08 & 1.07 & 1.00 & 1.43 & 1.07 & $1 \cdot 26$ & $1 \cdot 19$ & $1 \cdot 20$ \\
\hline $\mathrm{Cu}(\mathrm{mg} / \mathrm{kg} \mathrm{DM})$ & $18 \cdot 7$ & $22 \cdot 6$ & $21 \cdot 3$ & $28 \cdot 2$ & 23.5 & $25 \cdot 8$ & $25 \cdot 2$ & $27 \cdot 4$ & 21.5 \\
\hline $\mathrm{Zn}(\mathrm{mg} / \mathrm{kg} \mathrm{DM})$ & $30 \cdot 1$ & $35 \cdot 8$ & 35.9 & $37 \cdot 7$ & $34 \cdot 0$ & $36 \cdot 3$ & 33.7 & 33.9 & $32 \cdot 2$ \\
\hline $\mathrm{Mn}(\mathrm{mg} / \mathrm{kg} \mathrm{DM})$ & 100 & $96 \cdot 4$ & 105 & 97.9 & 113 & 115 & 117 & 99.5 & 101 \\
\hline
\end{tabular}

ADF, acid-detergent fibre.

${ }^{*} \mathrm{~S}$ is sodium sulfate supplement (level 0 , none; level $1,4.4 \mathrm{~g}$ sodium sulfate/kg DM, equivalent to $1 \mathrm{~g} \mathrm{~S} / \mathrm{kg} \mathrm{DM}$ ); Mo is ammonium molybdate supplement (level 0 , none; levels $1,2,3$ and $4,0.013,0.026,0.052$ and $0.103 \mathrm{~g}$ ammonium molybdate/kg DM, equivalent to 4, 8, 16 and $32 \mathrm{mg} \mathrm{Mo} / \mathrm{kg} \mathrm{DM}$, respectively).

†Contained (per g vitamin mix): retinol, $1 \mathrm{mg} ; \alpha$-tocopherol, $35 \mu \mathrm{g}$. 
S0Mo3, S1Mo1, S1Mo2 and S1Mo3) lambs per treatment and after 6 months (end of the experiment) all the remaining five lambs in each treatment were slaughtered following blood sampling and their livers were removed. All blood samples were taken from the jugular vein using heparinised vacuum tubes and the plasma was collected after centrifugation at $3500 \mathrm{rpm}$ for $30 \mathrm{~min}$ and stored at $-4^{\circ} \mathrm{C}$. The livers were frozen $\left(-20^{\circ} \mathrm{C}\right)$ until processing later. After thawing, the livers were sliced, blended and sampled. The samples were oven dried at $60^{\circ} \mathrm{C}$ until they reached cold constant weight, ground in a blender, and stored in plastic containers at $-20^{\circ} \mathrm{C}$ until analysed.

Crude protein in the diets and PKC samples were determined using the Kjedahl procedure, while acid-detergent fibre was determined according to Van Soest et al. ${ }^{(10)}$. Samples of PKC, diets, plasma and livers were digested in a nitric acidperchloric acid mixture and analysed for $\mathrm{Cu}, \mathrm{Fe}, \mathrm{Zn}, \mathrm{Ca}, \mathrm{Mg}$ and Mn using atomic absorption spectroscopy. Different standard solutions, including blank and five graded mineral concentrations, were prepared for each mineral element ( $\mathrm{Cu}, \mathrm{Fe}, \mathrm{Zn}, \mathrm{Ca}, \mathrm{Mg}$ and $\mathrm{Mn}$ ) and for each kind of sample (feed, liver and plasma). The measurements in the standard solutions were used for the calculation of mineral concentrations in the appropriate samples. The concentration of Mo in livers was determined according to Khan et al. ${ }^{(11)}$.

The experiment was a randomised complete block design with the sheep group fed the same experimental diet being the experimental unit. All results were statistically analysed as two-way ANOVA using the GLM procedure of SAS (SAS Institute, Inc., Cary, NC, USA) ${ }^{(12)}$ with treatment as the fixed effect and live weight group as the block. When the treatment effect was significant, Duncan's multiple-range test was used to determine the differences among treatment means and significance was declared at $P<0 \cdot 05$.

\section{Results}

Live weight, feed intake, daily gains and feed conversion efficiency

There were no significant differences among treatments in average live weight, dietary DM intake, daily gain and feed: gain ratio after 3 or 6 months of feeding the experimental diets (Table 2). The highest (126g) and the lowest (105g) average daily gains were recorded at 6 months for treatments S0Mo2 and S1Mo1, respectively. Similarly, overall 6-month feed intake ( $\mathrm{g} / \mathrm{d}$ per lamb) was lowest (650) for treatment S0Mo4 and highest (861) for treatment S1Mo4, while feed:gain ratio was lowest $(6 \cdot 07)$ for treatment S0Mo4 and highest $(7 \cdot 11)$ for treatment S1Mo4.

\section{Mineral element concentrations $(\mu \mathrm{g} / \mathrm{ml})$ in blood plasma}

There were no effects $(P>0.05)$ of treatments on the concentrations of $\mathrm{Cu}$ and $\mathrm{Zn}$ in blood plasma (Table 3 ). The initial $\mathrm{Cu}$ and $\mathrm{Zn}$ concentrations were similar to the concentrations recorded for individual treatments at the end of the experiment. The $\mathrm{Cu}$ concentrations ranged between 1·11 (treatment

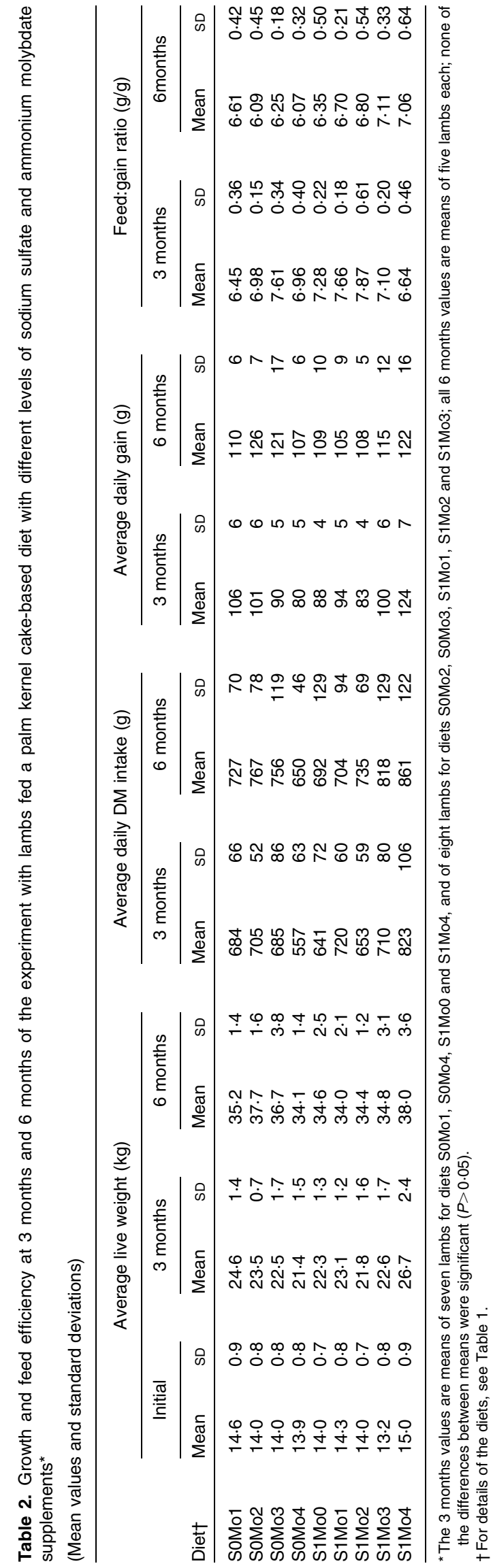


Table 3. Initial and final concentrations $(\mu \mathrm{g} / \mathrm{ml})$ of mineral elements in the blood plasma of lambs fed palm kernel cake-based diets with different levels of sodium sulfate and ammonium molybdate supplements* (Mean values and standard deviations)

\begin{tabular}{|c|c|c|c|c|c|c|c|c|c|c|}
\hline \multirow[b]{2}{*}{ Diet† } & \multicolumn{2}{|c|}{$\mathrm{Cu}$} & \multicolumn{2}{|c|}{$\mathrm{Fe}$} & \multicolumn{2}{|c|}{$\mathrm{Zn}$} & \multicolumn{2}{|c|}{$\mathrm{Ca}$} & \multicolumn{2}{|c|}{$\mathrm{Mg}$} \\
\hline & Mean & SD & Mean & SD & Mean & SD & Mean & SD & Mean & SD \\
\hline Initial & 1.31 & 0.06 & $4 \cdot 66^{a, b}$ & 0.35 & 1.49 & 0.14 & $173^{d}$ & 10 & $23 \cdot 5^{b}$ & $1 \cdot 1$ \\
\hline S0Mo1 & 1.38 & 0.11 & $4.93^{\mathrm{a}}$ & 0.16 & 1.50 & 0.09 & $84^{\mathrm{b}, \mathrm{c}}$ & 8 & $24 \cdot 8^{a, b}$ & 1.3 \\
\hline SOMo2 & 1.33 & 0.13 & $3 \cdot 56^{c, d}$ & 0.33 & 1.55 & 0.08 & $81^{\mathrm{b}, \mathrm{c}}$ & 6 & $26 \cdot 8^{\mathrm{a}, \mathrm{b}}$ & 1.1 \\
\hline S0Mo3 & 1.50 & 0.25 & $3 \cdot 77^{b, c}$ & 0.31 & 1.48 & 0.17 & $90^{\mathrm{a}, \mathrm{b}, \mathrm{c}}$ & 9 & $30 \cdot 7^{\mathrm{a}}$ & $3 \cdot 2$ \\
\hline SOMo4 & 1.25 & 0.19 & $3 \cdot 34^{c, d}$ & 0.17 & 1.29 & 0.20 & $84^{\mathrm{b}, \mathrm{c}}$ & 5 & $25 \cdot 2^{a, b}$ & 3.9 \\
\hline S1Mo0 & 1.27 & 0.09 & $4.58^{a, b}$ & 0.52 & 1.60 & 0.12 & $111^{\mathrm{a}}$ & 8 & $25 \cdot 0^{a, b}$ & $2 \cdot 3$ \\
\hline S1Mo1 & $1 \cdot 11$ & 0.10 & $2 \cdot 93^{\mathrm{d}}$ & 0.24 & 1.57 & 0.26 & $78^{c}$ & 16 & $24 \cdot 2^{b}$ & $2 \cdot 1$ \\
\hline S1Mo2 & 1.52 & 0.16 & $3 \cdot 58^{c, d}$ & 0.13 & 1.60 & 0.10 & $104^{a, b}$ & 9 & $25 \cdot 6^{a, b}$ & 1.0 \\
\hline S1Mo3 & $1 \cdot 27$ & 0.09 & $3 \cdot 33^{c, d}$ & 0.16 & 1.38 & 0.22 & $77^{\mathrm{C}}$ & 2 & $21.9^{b}$ & 0.7 \\
\hline S1Mo4 & 1.30 & 0.22 & $3.09^{c, d}$ & 0.37 & 1.14 & 0.29 & $98^{\mathrm{a}, \mathrm{b}, \mathrm{c}}$ & 8 & $23 \cdot 2^{b}$ & 1.3 \\
\hline
\end{tabular}

a,b,c,d Mean values within a column with unlike superscript letters were significantly different $(P<0.05)$.

* The initial values are means of eight lambs and the final values are means of five lambs.

†For details of the diets, see Table 1.

S1Mo1) and 1.52 (treatment S1Mo2), while those of $\mathrm{Zn}$ ranged between 1.14 (treatment S1Mo4) and 1.60 (treatments S1Mo0 and $\mathrm{S} 1 \mathrm{Mo} 2)$.

The highest (4.93) and lowest (2.93) plasma concentrations of Fe $(P<0.05)$ were obtained for treatments S0Mo1 and S1Mo1, respectively. The concentrations for treatments S0Mo2, S0Mo4, S1Mo1, S1Mo2, S1Mo3 and S1Mo4 were lower $(P<0.05)$ than the initial concentration and that for treatment S0Mo1. In addition, the Fe concentration for treatment S0Mo3 was lower $(P<0 \cdot 05)$ than for treatment S0Mo1.

The plasma concentration of $\mathrm{Ca}$ was significantly higher initially than for all treatments at the end of the experiment. It was also higher $(P<0.05)$ at the end of the experiment for treatments $\mathrm{S} 1 \mathrm{Mo} 0$ and $\mathrm{S} 1 \mathrm{Mo} 2$ than for treatments $\mathrm{S} 1 \mathrm{Mo} 1$ and S1Mo3, and lower $(P<0.05)$ for treatments S0Mo1, S0Mo2 and S0Mo4 than for treatment S1Mo0.

The plasma concentration of $\mathrm{Mg}$ ranged from 21.9 (treatment S1Mo3) to $30 \cdot 7$ (treatment SOMo3). The concentration was higher $(P<0.05)$ for treatment $\mathrm{S} 1 \mathrm{Mo0}$ than the initial concentration and for treatments S1Mo1, S1Mo3 and S1Mo4. The rest of the differences were not significant.

\section{Mineral element concentrations ( $\mu g / g D M)$ in the liver}

In comparison with the initial value (376), the liver $\mathrm{Cu}$ concentration within the first 3 months of the experiment (Table 4) significantly increased only for treatment S1Mo0 (1258), but there were also other treatments (SOMo1, SOMo2 and S0Mo3) that reached values of over 1000 (1069 to 1137). One treatment (S1Mo4) showed a numerical value (161) that was apparently lower than the initial value (376), but at the end of the experiment ( 6 months) there were three treatments (S1Mo2, S1Mo3 and S1Mo4) with apparent values (254 to 327) being lower than the initial. The liver $\mathrm{Cu}$ concentrations at 6 months of the experiment for treatments S0Mo1, SOMo2, S0Mo3 and S1Mo0 were all over the value of 1000

Table 4. Initial, 3 months and 6 months concentrations ( $\mu \mathrm{g} / \mathrm{g} \mathrm{DM}$ ) of micro-minerals in the liver of lambs after feeding palm kernel cake-based diets with different levels of sodium sulfate and ammonium molybdate supplements*

(Mean values and standard deviations)

\begin{tabular}{|c|c|c|c|c|c|c|c|c|c|c|c|c|c|c|c|c|}
\hline \multirow[b]{3}{*}{ Diet† } & \multicolumn{4}{|c|}{$\mathrm{Cu}$} & \multicolumn{4}{|c|}{$\mathrm{Zn}$} & \multicolumn{4}{|c|}{$\mathrm{Mn}$} & \multicolumn{4}{|c|}{ Mo } \\
\hline & \multicolumn{2}{|c|}{3 months } & \multicolumn{2}{|c|}{6 months } & \multicolumn{2}{|c|}{3 months } & \multicolumn{2}{|c|}{6 months } & \multicolumn{2}{|c|}{3 months } & \multicolumn{2}{|c|}{6 months } & \multicolumn{2}{|c|}{3 months } & \multicolumn{2}{|c|}{6 months } \\
\hline & Mean & SD & Mean & SD & Mean & SD & Mean & SD & Mean & SD & Mean & SD & Mean & SD & Mean & SD \\
\hline Initial & $376^{\mathrm{b}}$ & 45 & $376^{\mathrm{b}}$ & 45 & 177 & 20 & $177^{a}$ & 20 & $17 \cdot 5$ & 0.6 & $17 \cdot 5^{a, b}$ & 0.6 & $6 \cdot 00^{b}$ & 0.42 & $6 \cdot 00^{b, c}$ & 0.42 \\
\hline S0Mo1 & $1069^{a, b}$ & 168 & $1090^{a}$ & 182 & 141 & 33 & $131^{a, b}$ & 7 & $11 \cdot 0$ & 2.2 & $11 \cdot 6^{\mathrm{b}}$ & 1.4 & $5 \cdot 35^{b}$ & 0.08 & $5 \cdot 81^{\mathrm{b}, \mathrm{c}}$ & 0.49 \\
\hline S0Mo2 & $1100^{a, b}$ & 282 & $1294^{a}$ & 201 & 140 & 9 & $167^{a, b}$ & 23 & $12 \cdot 4$ & 0.8 & $14 \cdot 1^{b}$ & $1 \cdot 3$ & $10 \cdot 08^{a}$ & 0.82 & $5 \cdot 88^{\mathrm{b}, \mathrm{c}}$ & 0.62 \\
\hline S0Mo3 & $1137^{a, b}$ & 100 & $1211^{a}$ & 285 & 121 & 9 & $117^{a, b}$ & 6 & 23.0 & $7 \cdot 4$ & $21.9^{\mathrm{a}}$ & 4.4 & $7 \cdot 92^{a, b}$ & 0.50 & $6.57^{\mathrm{a}, \mathrm{b}, \mathrm{c}}$ & 0.89 \\
\hline SOMo4 & $378^{b}$ & 0 & $776^{\mathrm{a}, \mathrm{b}}$ & 63 & 114 & 1 & $120^{a, b}$ & 2 & $17 \cdot 8$ & $5 \cdot 0$ & $19 \cdot 1^{a, b}$ & $1 \cdot 3$ & $6 \cdot 47^{\mathrm{b}}$ & 0.71 & $7 \cdot 09^{a, b, c}$ & 0.74 \\
\hline S1Mo0 & $1258^{a}$ & 70 & $1259^{a}$ & 197 & 118 & 8 & $141^{a, b}$ & 21 & 13.5 & 5.0 & $13 \cdot 7^{\mathrm{b}}$ & 1.3 & $4.95^{b}$ & 1.06 & $5.42^{\mathrm{C}}$ & 0.77 \\
\hline S1Mo1 & $377^{b}$ & 58 & $573^{b}$ & 122 & 119 & 7 & $100^{b}$ & 12 & $21 \cdot 3$ & 0.7 & $13 \cdot 7^{b}$ & $1 \cdot 7$ & $6 \cdot 85^{b}$ & 0.71 & $5 \cdot 76^{\mathrm{b}, \mathrm{c}}$ & 0.42 \\
\hline S1Mo2 & $380^{\mathrm{b}}$ & 154 & $327^{b}$ & 73 & 118 & 6 & $120^{a, b}$ & 4 & $17 \cdot 2$ & $2 \cdot 0$ & $14 \cdot 1^{b}$ & 1.5 & $5 \cdot 88^{\mathrm{b}, \mathrm{c}}$ & 1.04 & $6 \cdot 88^{a, b, c}$ & 0.44 \\
\hline S1Mo3 & $416^{b}$ & 181 & $257^{\mathrm{b}}$ & 17 & 125 & 7 & $116^{a, b}$ & 7 & $15 \cdot 8$ & 2.5 & $10 \cdot 8^{b}$ & $2 \cdot 0$ & $6 \cdot 16^{\mathrm{b}}$ & 0.93 & $9 \cdot 06^{\mathrm{a}}$ & 0.71 \\
\hline S1Mo4 & $161^{\mathrm{b}}$ & 82 & $254^{\mathrm{b}}$ & 80 & 129 & 6 & $116^{a, b}$ & 13 & $21 \cdot 3$ & 0.7 & $12 \cdot 1^{b}$ & 1.0 & $7 \cdot 55^{\mathrm{a}, \mathrm{b}}$ & 0.50 & $8.56^{a, b}$ & 0.88 \\
\hline
\end{tabular}

a,b,c Mean values within a column with unlike superscript letters were significantly different $(P<0.05)$.

*The initial values are means of eight lambs, the 3 months values are means of two lambs for diets S0Mo1, S0Mo4, S1Mo0 and S1Mo4, and of three lambs for diets S0Mo2, S0Mo3, S1Mo1, S1Mo2 and S1Mo3; all 6 months values are means of five lambs each.

†For details of the diets, see Table 1. 
(1090 to 1294) and significantly higher than the initial concentration and those for the other treatments (S1Mo1, S1Mo2, S1Mo3 and S1Mo4), except that S0Mo4 that was not different $(P>0.05)$ from any other treatments or from the initial concentration.

The liver concentrations of $\mathrm{Zn}$ at 3 months of the experiment were not different $(P>0.05)$ among the treatments or from the initial value. However, at the end of the experiment (6 months) the initial liver $\mathrm{Zn}$ concentration was numerically higher than those of all treatments and different $(P<0.05)$ from treatment S1Mo1. Similarly, there were no differences $(P>0.05)$ in the liver Mn concentration at 3 months of the experiment. However, at 6 months, although the initial value was not different $(P>0.05)$ from the values of all treatments, the concentration for treatment S0Mo3 was higher $(P<0.05)$ than for other treatments, except for treatment S0Mo4. The liver Mo concentration at 3 months of the experiment was higher $(P<0.05)$ for treatment S0Mo2 $(10 \cdot 1)$ than was the initial concentration $(6.00)$, but was not different $(P>0.05)$ from treatments S0Mo3 and S1Mo4. At the end of the experiment (6 months) the concentration of Mo was higher $(P<0.05)$ for treatment S1Mo3 (9.06) than was the initial value (6.00), but the differences between the initial value and those for all other treatments were not significant.

There were no significant differences in the liver Ca concentrations (Table 5). Similarly, there were no significant differences in the concentrations of Fe and $\mathrm{Mg}$ at 3 months of the experiment. However, in comparison with the initial liver Fe value the concentrations for all treatments numerically increased by the end of the experiment ( 6 months) and the differences were significant for treatments S1Mo0, S1Mo1, S1Mo2, S1Mo3 and S1Mo4. There were no significant differences in the liver Fe concentration among treatment means. Concerning the final 6-month liver $\mathrm{Mg}$ concentration, the numerical values for all treatments (499 to 655) were apparently lower than the initial value (695), but the differences were significant only for treatment S1Mo1 (499). There were no significant differences in the liver $\mathrm{Mg}$ concentrations among the treatment means.

\section{Discussion}

The results of the present experiment clearly show that both $S$ and Mo supplements are needed to maintain normal concentrations of $\mathrm{Cu}$ in the liver of sheep fed a PKC monodiet. Such supplements did not affect growth and feed intake. It has been established ${ }^{(13)}$ in sheep liver that $\mathrm{Cu}$ concentrations of up to $500 \mathrm{mg} / \mathrm{kg} \mathrm{DM}$ are considered normal, but that over $800 \mathrm{mg} / \mathrm{kg}$ DM hypercuprosis and stress-induced haemolytic crisis may develop. In the present experiment, treatment S1Mo2, consisting of a PKC monodiet supplemented (per kg $\mathrm{DM}$ ) with $1 \mathrm{~g} \mathrm{~S}$ and $8 \mathrm{mg}$ Mo (resulting in overall dietary concentrations of $\mathrm{S}$ and Mo of approximately $3 \mathrm{~g}$ and $8.8 \mathrm{mg} / \mathrm{kg}$ dietary $\mathrm{DM}$, respectively) produced optimal results. The growth, feed intake and plasma $\mathrm{Cu}$ concentrations were normal and not affected by the supplements. More importantly, the liver concentrations of $\mathrm{Cu}$ and $\mathrm{Mo}$ were also normal and not different from the initial concentrations. In addition, treatment S1Mo1 with the same amount of dietary S (3 g/ kg DM) but lower dietary Mo $(4.8 \mathrm{mg} / \mathrm{kg} \mathrm{DM})$ produced a higher liver $\mathrm{Cu}$ concentration $(573 \mathrm{mg} / \mathrm{kg} \mathrm{DM}$ ) than is considered normal (up to $500 \mathrm{mg} / \mathrm{kg}$ $\mathrm{DM}$ ), while treatments S1Mo3 and S1Mo4, providing the same amount of the dietary $\mathrm{S}$ but more $(16.8$ and $32.8 \mathrm{mg} / \mathrm{kg}$ $\mathrm{DM}$, respectively) dietary $\mathrm{Mo}$, produced the same liver $\mathrm{Cu}$ concentration as treatment $\mathrm{S} 1 \mathrm{Mo} 2$, but with elevated liver Mo concentrations. It should be pointed out that these elevated liver Mo concentrations for treatments S1Mo3 and S1Mo4 were significantly higher than the liver $\mathrm{Cu}$ concentration for treatment S1Mo0, while the liver Mo concentration for treatment S1Mo2 was not.

Considering that the range of $\mathrm{Cu}$ concentration in Malaysian PKC is from 11 to $55 \mathrm{mg} / \mathrm{kg} \mathrm{DM}^{(1-3)}$ the presently used PKC with an average $\mathrm{Cu}$ concentration of 25 (SD 9) $\mathrm{mg} / \mathrm{kg} \mathrm{DM}$ is close to the middle of the range and probably represents the

Table 5. Initial, 3 months and 6 months concentrations ( $\mu \mathrm{g} / \mathrm{g} \mathrm{DM}$ ) of macro-minerals in the liver of lambs after feeding a palm kernel cake-based diet with different levels of sodium sulfate and ammonium molybdate supplements*

(Mean values and standard deviations)

\begin{tabular}{|c|c|c|c|c|c|c|c|c|c|c|c|c|}
\hline & \multicolumn{2}{|c|}{3 months } & \multicolumn{2}{|c|}{6 months } & \multicolumn{2}{|c|}{3 months } & \multicolumn{2}{|c|}{6 months } & \multicolumn{2}{|c|}{3 months } & \multicolumn{2}{|c|}{6 months } \\
\hline Diet† & Mean & SD & Mean & SD & Mean & SD & Mean & SD & Mean & $\mathrm{SD}$ & Mean & $\mathrm{SD}$ \\
\hline Initial & 171 & 29 & $171^{b}$ & 29 & 695 & 40 & $695^{a}$ & 40 & 186 & 16 & 186 & 16 \\
\hline S0Mo3 & 206 & 33 & $278^{a, b}$ & 49 & 577 & 50 & $639^{a, b}$ & 35 & 188 & 15 & 190 & 19 \\
\hline SOMo4 & 210 & 67 & $282^{a, b}$ & 48 & 603 & 87 & $568^{a, b}$ & 19 & 185 & 20 & 170 & 8 \\
\hline $\mathrm{S} 1 \mathrm{Mo0}$ & 177 & 35 & $411^{a}$ & 37 & 434 & 206 & $587^{a, b}$ & 28 & 140 & 56 & 185 & 4 \\
\hline S1Mo1 & 253 & 31 & $444^{a}$ & 45 & 612 & 26 & $499^{b}$ & 69 & 147 & 10 & 149 & 21 \\
\hline S1Mo2 & 263 & 69 & $474^{a}$ & 63 & 565 & 28 & $528^{a, b}$ & 39 & 139 & 10 & 166 & 11 \\
\hline S1Mo3 & 259 & 17 & $470^{a}$ & 70 & 541 & 12 & $548^{a, b}$ & 13 & 179 & 8 & 174 & 12 \\
\hline
\end{tabular}

a,b Mean values within a column with unlike superscript letters were significantly different $(P<0.05)$.

*The initial values are means of eight lambs, the 3 months values are means of two lambs for diets S0Mo1, S0Mo4, S1Mo0 and S1Mo4, and of three lambs for diets S0Mo2, S0Mo3, S1Mo1, S1Mo2 and S1Mo3; all 6 months values are means of five lambs each.

†For details of the diets, see Table 1. 
$\mathrm{Cu}$ concentration in the majority of the PKC produced in Malaysia. In addition, the diets used in the present experiment were based entirely on PKC. Therefore, if we consider the S and Mo supplements in treatment $\mathrm{S} 1 \mathrm{Mo} 2$ as optimal for preventing chronic $\mathrm{Cu}$ toxicity and excessive accumulation of $\mathrm{Cu}$ and $\mathrm{Mo}$ in the liver, then it would be logical to assume that the dietary supplements of approximately $1 \mathrm{~g} \mathrm{~S}$ and $8 \mathrm{mg}$ Mo are required per $\mathrm{kg}$ PKC DM to be used in the diet. This would be appropriate for lambs that were not previously fed untreated PKC and having a normal liver $\mathrm{Cu}$ concentration. Otherwise, much higher amounts of the dietary Mo supplement might be needed.

It has been reported that during the later part of the prehaemolytic stage and the haemolytic stage of $\mathrm{Cu}$ toxicity, liver $\mathrm{Cu}$ concentrations may range from 1000 to $3000 \mathrm{mg} / \mathrm{kg} \mathrm{DM}^{(13)}$. In reported $\mathrm{Cu}$ poisoning in a sheep flock ${ }^{(14)}$ the average monthly hepatic $\mathrm{Cu}$ concentrations in sheep that died of $\mathrm{Cu}$ toxicity were between 745 and $1251 \mathrm{mg} / \mathrm{kg}$ DM. To rapidly reduce death losses ${ }^{(14)}$ a treatment with dietary supplements of $0.1 \mathrm{~g}$ ammonium molybdate and $1 \mathrm{~g}$ sodium sulfate per sheep per d was used, but after 4 months there were still dead sheep with high hepatic concentrations. In another case, $500 \mathrm{mg}$ ammonium molybdate per kg dietary DM completely eliminated deaths of sheep from $\mathrm{Cu}$ toxicity within 5 months ${ }^{(15)}$. In contrast, together with $\mathrm{S}$ the dietary Mo supplements between 4 and $23 \mathrm{mg} / \mathrm{kg}$ DM were effective to reduce hepatic $\mathrm{Cu}$ concentration to normal levels ${ }^{(8,16-18)}$. However, the effectiveness of dietary Mo supplements may depend on the initial $\mathrm{Cu}$ status of the animal ${ }^{(19)}$ and on the dietary $\mathrm{Cu}$ concentration and its biological availability for absorption and utilisation. Indeed, the rumen solubility ${ }^{(5)}$ and biological availability of $\mathrm{Cu}$ in PKC may be quite high due to elimination of the protozoa population in the rumen by the dietary $\mathrm{PKC}^{(7)}$. The increase in the $\mathrm{Cu}$ bioavailability due to the elimination of ciliate protozoa from the rumen might amount to between 15 and $50 \%{ }^{(6,20)}$. Nevertheless, supplements of $4.4 \mathrm{~g} \mathrm{Na}_{2} \mathrm{SO}_{4}$ and $25.8 \mathrm{mg}\left(\mathrm{NH}_{4}\right)_{6} \mathrm{Mo}_{7} \mathrm{O}_{24} \cdot 4 \mathrm{H}_{2} \mathrm{O}$ per $\mathrm{kg}$ of the dietary PKC were optimal in the present experiment to maintain over the 6-month period appropriate hepatic concentrations of $\mathrm{Cu}$ and $\mathrm{Mo}$ in normal lambs.

It was established decades ago that dietary Mo in the presence of adequate $\mathrm{S}$ can reduce the hepatic $\mathrm{Cu}$ accumulation and storage $\mathrm{e}^{(21-25)}$ and that both organic and inorganic $\mathrm{S}$ affect the absorption of $\mathrm{Cu}$ to a limited degree only ${ }^{(22,26)}$. However, the present experiment showed that it is possible to feed PKC monodiets to normal lambs without $\mathrm{Cu}$ or $\mathrm{Mo}$ toxicosis when supplements of $4.4 \mathrm{~g} \mathrm{Na}_{2} \mathrm{SO}_{4}$ and $25.8 \mathrm{mg}$ $\left(\mathrm{NH}_{4}\right)_{6} \mathrm{MO}_{7} \mathrm{O}_{24} \cdot 4 \mathrm{H}_{2} \mathrm{O}$ (or $1 \mathrm{~g} \mathrm{~S}$ and $8 \mathrm{mg} \mathrm{Mo}$ ) per kg dietary $\mathrm{PKC}$ are used. In addition to high concentrations of $\mathrm{Cu}, \mathrm{PKC}$ is also high in the concentrations of $\mathrm{P}$ and $\mathrm{Fe}$. The $\mathrm{Ca}: \mathrm{P}$ ratio can be easily corrected by a $\mathrm{Ca}$ supplement. The range of Fe concentration in PKC is between 0.8 and $6 \mathrm{~g}$ per $\mathrm{kg}$ DM (1.2 (SD 0.7) $\mathrm{g} / \mathrm{kg} \mathrm{DM}$ in the PKC used in the present experiment). Excessive dietary concentrations of $\mathrm{Fe}$ may result in bent legs of lambs ${ }^{(27)}$ and in decreased productivity of dairy cows ${ }^{(28)}$. Although the $\mathrm{S}$ plus Mo supplements in the present experiment decreased the concentration of Fe in blood plasma, the concentrations in the liver were actually increased. The increase in the hepatic Fe concentration due to $S$ plus Mo supplements is contrary to a previous report ${ }^{(8)}$ and the reason is presently not known. Besides the effects of dietary S and Mo supplements on the hepatic concentrations of $\mathrm{Cu}, \mathrm{Mo}$ and $\mathrm{Fe}$ the concentrations of other measured elements ( $\mathrm{Zn}, \mathrm{Mn}, \mathrm{Mg}$ and $\mathrm{Ca}$ ) were not affected appreciably by the supplements.

In conclusion, supplements of $4-5 \mathrm{~g} \mathrm{Na}_{2} \mathrm{SO}_{4}$ and $26 \mathrm{mg}$ $\left(\mathrm{NH}_{4}\right)_{6} \mathrm{MO}_{7} \mathrm{O}_{24} \cdot 4 \mathrm{H}_{2} \mathrm{O}$ (or $1 \mathrm{~g} \mathrm{~S}$ plus $8 \mathrm{mg} \mathrm{Mo}$ ) per $\mathrm{kg}$ PKC $\mathrm{DM}$ mixed into the PKC used are sufficient to maintain lambs on diets containing any amount of PKC (including PKC monodiets) without an excessive hepatic accumulation of $\mathrm{Cu}$ and $\mathrm{Mo}$, and without potential chronic $\mathrm{Cu}$ poisoning. Therefore, the present results suggest that any amount of PKC treated with appropriate S, Mo and Ca (to balance for excessive $\mathrm{P}$ concentrations in $\mathrm{PKC}$ ) supplements can be incorporated in the diets of ruminants. This is under condition that the other dietary ingredients do not contain an excessive $\mathrm{Cu}$ concentration. It should be emphasised, however, that in comparison with other feeds, PKC is unique. First, PKC contains an unusually high concentration (11 to $55 \mu \mathrm{g} / \mathrm{g}$ DM) of $\mathrm{Cu}^{(1-3)}$. Second, the $\mathrm{Cu}$ in $\mathrm{PKC}$ is rapidly released and highly soluble in the rumen ${ }^{(5)}$. Third, PKC reduces or eliminates protozoa from the rumen ${ }^{(7)}$ due to its relatively high content of oil that is toxic to rumen ciliate protozoa ${ }^{(29,30)}$. It has been documented $^{(6,20,31,32)}$ that elimination of protozoa from the rumen increases the dietary $\mathrm{Cu}$ bioavailability and accumulation in the liver of sheep. Therefore, the present results on the need of the dietary $\mathrm{S}$ and Mo supplements to eliminate the risk of chronic $\mathrm{Cu}$ toxicity due to dietary PKC cannot be extrapolated to other potential high-Cu feeds used as the dietary ingredient. In Malaysia the presently allowed up to $30 \%$ inclusion of PKC in diets of sheep due to the potential $\mathrm{Cu}$ toxicity problem may be extended to any amounts of up to PKC monodiets (PKC plus appropriate vitamins and mineral supplements) for all ruminants with the condition that an appropriate dietary supplement of S plus Mo is mixed in the PKC used. However, the animal acceptability, practicability, and the ruminant production efficiency of diets containing high amounts of PKC (over 50\%) or of PKC monodiets have not been established; additional experiments are needed to elucidate the optimal and practical dietary PKC concentrations in ruminants. This would expand the safe use of PKC, which is in abundance in Malaysia, as a common feed for all ruminants.

\section{Acknowledgements}

This research received no specific grant from any funding agency in the public, commercial or not-for-profit sectors.

A. R. A. facilitated supplies, and supervised experimental work, chemical analysis and evaluation of the results, while M. I. developed the hypothesis and experimental protocol and wrote the manuscript. S. J. provided guidance and consultations throughout the course of the study. The authors thank Ms Li Juan for conducting the experimental work with lambs, chemical analysis, and the calculation and tabulation of results.

There are no conflicts of interest. 


\section{References}

1. Jalaludin S (1995) Feeding systems based on palm oil products and by-products. In Animal Science and Development: Moving Towards a New Century, pp. 295-306 [M Ivan, editor]. Ottawa, Canada: Centre for Food and Animal Research.

2. Rahman AMY, Wong HK \& Zaini H, et al. (1989) Preliminary observation on the alleviation of copper in sheep fed with palm kernel meal based diet In Proceedings of 12th Malaysian Society of Animal Production (MSAP) Conference, Malaysia, pp. 75-78. Kuala Lumpur: Malaysian Society of Animal Production (MSAP).

3. Jalaludin S, Jelan ZA \& Abdulah N, et al. (1991) Recent developments in the oil palm by-product based ruminant feeding system In Proceedings of the 3rd International Symposium on Nutrition of Herbivores, Malaysia, pp. 35-44. Kuala Lumpur: Malaysian Society of Animal Production (MSAP).

4. Underwood EJ (1966) The Mineral Nutrition of Livestock. Aberdeen: The Central Press Ltd.

5. Jin LZ, Alimon AR, Abdulah N, et al. (1995) Minerals released from palm kernel cake (PKC) and corn-soybean concentrate + copper in the rumen of goats. Mal J Anim Sci 1, 41-44.

6. Ivan M, Veira DM \& Kelleher CA (1986) The alleviation of chronic copper toxicity in sheep by ciliate protozoa. $\mathrm{Br} J$ Nutr 55, 361-367.

7. Abubakr AR, Alimon AR, Yaakub H, et al. (2011) Effects of dietary palm oil by-products on rumen fermentation, digestibility and total rumen protozoa population in goats. Animal (In the Press).

8. Ivan M, Rusihan M, Alimon AR, et al. (1999) The efficacy of dietary supplements of bentonite and sulphur plus molybdenum to alleviate chronic copper toxicity in sheep fed palm kernel cake. CzJ Anim Sci 44, 125-130.

9. Alimon AR \& Hair-Bejo M (1995) Feeding systems based on oil palm by-products in Malaysia. In Proceedings of the First International Symposium on the Integration of Livestock to Oil Palm Production, pp. 155-157. Kuala Lumpur: Malaysian Society of Animal Production (MSAP)/FAO.

10. Van Soest PJ, Robertson JB \& Lewis BA (1991) Methods for dietary fiber, neutral detergent fiber, and monostarch polysaccharides in relation to animal nutrition. J Dairy Sci 74, 3583-3597.

11. Khan U, Cloutier RO \& Hidiroglou M (1979) Atomic absorption spectroscopic determination of molybdenum in plant tissue and blood plasma. J Assoc Off Anal Chem 62, 1062-1064.

12. SAS (2004) Statistical Analytical System. Cary, NC: SAS Institute Inc.

13. Bostwick JL (1982) Copper toxicosis in sheep. J Am Vet Med Assoc 180, 386-387.

14. Hidiroglou M, Heaney DP \& Hartin KE (1984) Copper poisoning in a flock of sheep. Copper excretion patterns after treatment with molybdenum and sulfur or penicillamine. Can Vet J 25, 377-382.

15. Hair-Bejo M \& Alimon AR (1992) Hepatic damages and the protective role of zinc and molybdate in palm kernel cake toxicity in sheep. In Proceedings of 15th Malaysian Society of Animal Production (MSAP) Annual Conference, Malaysia, pp. 93-95. Kuala Lumpur: Malaysian Society of Animal Production (MSAP).

16. Kline RD, Hays VW \& Cromwel GL (1971) Effects of copper, molybdenum and sulfate on performance, hematology and copper stores of pigs and lambs. J Anim Sci 33, 771-779.

17. Suttle NF (1977) Reducing the potential copper toxicity of concentrates to sheep by the use of molybdenum and sulphur supplements. Anim Feed Sci Technol 2, 235-246.

18. Van der Schee W, Garretsen JW \& Van der Berg R (1980) Effect of zinc and molybdenum supplementation of the feed concentrate on the stage of copper in the liver of lambs. Vet Quart 2, 82-89.

19. Gray LF \& Daniel LJ (1964) Effect of the copper status of the rat on the copper-molybdenum-sulfate interaction. $J$ Nutr 84, 31-37.

20. Ivan M \& Entz T (2007) Comparison of effects of Isotricha monofauna and total mixed fauna on dietary copper metabolism in lambs. Can J Anim Sci 87, 401-405.

21. Dick AT (1954) Studies on the assimilation and storage of copper in crossbred sheep. Aust J Agric Res 5, 511-544.

22. Suttle NF (1974) Effects of organic and inorganic sulphur on the availability of dietary copper to sheep. Br J Nutr 32, 559-568.

23. Ross DB (1966) The diagnosis, prevention and treatment of chronic copper poisoning in housed lambs. Br Vet J 122, 279-284.

24. Ross DB (1970) The effect of oral ammonium molybdate and sodium sulphate given to lambs with high liver copper concentrations. Br Vet J 11, 295-297.

25. Hogan KG, Money DFL \& Blayney A (1968) The effect of molybdate and sulphate supplement on the accumulation of copper in the liver of penned sheep. $N Z J$ Agric Res 11, 435-444.

26. Suttle NF (1975) The role of organic sulphur in the coppermolybdenum-S interrelationship in ruminant nutrition. $\mathrm{Br} \mathrm{J}$ Nutr 34, 411-420.

27. Hidiroglou M, Dukes TW, Ho SK, et al. (1978) Bent-limb syndrome in lambs raised in total confinement. J Am Vet Ass 173, 1571-1574.

28. Coup MR \& Campbell AG (1964) The effect of excessive iron intake upon the health and production of dairy cows. $N Z J$ Agric Res 7, 624-638.

29. Ivan M, Mir PS, Koenig KM, et al. (2001) Effects of dietary sunflower seed oil on protozoal population in the rumen, growth, and the tissue concentration of fatty acids including conjugated linoleic acid in sheep. Small Rum Res 41, $215-227$.

30. Ivan M, Entz T, Mir PS, et al. (2003) Effects of the dietary sunflower seed supplementation and different dietary protein concentrations on the ciliate protozoa population dynamics in the rumen of sheep. Can J Anim Sci 83, 809-817.

31. Ivan M (1988) Effect of faunation on ruminal solubility and liver content of copper in sheep fed low or high copper diets. J Anim Sci 66, 1496-1501.

32. Ivan M (1989) Effects of faunation and type of dietary protein on gastric solubility and liver content of copper in sheep. J Anim Sci 67, 3028-3035. 